\title{
Development of a Reverse Transcription Loop-Mediated Isothermal Amplification Assay for H7N7 Equine Influenza Virus
}

\author{
Manabu NEMOTO1)*, Takashi YAMANAKA ${ }^{1)}$, Hiroshi BANNAI ${ }^{1)}$, Koji TSUJIMURA ${ }^{1)}$, Takashi KONDO $^{1)}$ and \\ Tomio MATSUMURA ${ }^{1)}$ \\ ${ }^{1)}$ Epizootic Research Center, Equine Research Institute, Japan Racing Association, 1400-4 Shiba, Shimotsuke, Tochigi 329-0412, Japan
}

(Received 1 December 2011/Accepted 12 February 2012/Published online in J-STAGE 24 February 2012)

ABSTRACT. We have developed a reverse transcription loop-mediated isothermal amplification (RT-LAMP) assay for detecting H7N7 equine influenza virus (EIV). The detection limit of the RT-LAMP assay was a virus dilution of $10^{-4}$, which was 10 times more sensitive than that of Espline Influenza A\&B-N and the same as that of reverse transcription polymerase chain reaction. The RT-LAMP assay specifically amplified H7N7 EIV strains but did not amplify several pathogens related to equine respiratory disease including H3N8 EIV strains. Because it provides ease of manipulation, the RT-LAMP assay is suitable for large-scale surveillance for H7N7 EIV. In addition, the combination of the H3N8 RT-LAMP assay, which was developed previously, with the H7N7 RT-LAMP assay should be useful to discriminate between H3N8 and H7N7 EIVs in clinical laboratories.

KEY WORDS: equine influenza virus, H7N7, reverse transcription loop-mediated isothermal amplification.

doi: 10.1292/jvms.11-0541; J. Vet. Med. Sci. 74(7): 929-931, 2012

Equine influenza is one of the most important respiratory diseases of horses because of its rapid transmission. It is caused by influenza A viruses of the H3N8 or H7N7 subtype $[11,15]$. Equine influenza virus (EIV) of the H3N8 subtype (H3N8 EIV), which was first isolated in 1963, continues to circulate among horses worldwide $[11,15]$. In contrast, EIV of the H7N7 subtype (H7N7 EIV), which was first isolated in 1956, has not been isolated from horses since 1979 [11, 15]. However, antibodies against H7N7 EIV were found in unvaccinated horses in 1994 [3], and H7N7 EIV may therefore still persist at very low levels in a subclinical form [11, 15]. Large-scale surveillance using nasal samples is needed to determine whether H7N7 EIV exists in the equine population of the world.

Traditionally, the gold standard for the diagnosis of H7N7 EIV has been virus isolation from nasal swabs by using embryonated hen's eggs and/or MDCK cells [15]. Molecular diagnostic methods, such as reverse transcription polymerase chain reaction (RT-PCR) and real-time RT-PCR, have been introduced for specific detection of H7N7 EIV $[2,10]$. However, these methods require time-consuming processes or expensive equipment. Some rapid antigen detection kits, such as Directigen Flu A (Becton, Dickinson and Company, Sparks, MD, U.S.A.), the BinaxNOW Flu A test kit (Binax Inc., Scarborough, ME, U.S.A.) and the Espline Influenza A\&B-N (Espline; Fujirebio Inc., Tokyo, Japan), are applied to the diagnosis of EIV [1, 4, 6, 12, 16]. The procedures of these kits are simple, easy and rapid

*Correspondence to: Nemoto, M., Epizootic Research Center, Equine Research Institute, Japan Racing Association, 1400-4 Shiba, Shimotsuke, Tochigi 329-0412, Japan.

e-mail: nemoto_manabu@epizoo.equinst.go.jp

(C) 2012 The Japanese Society of Veterinary Science without requiring additional reagents and equipment. However, these kits are less sensitive than virus isolation and molecular diagnostic methods $[8,12,13,16]$ and cannot distinguish between H7N7 and H3N8 EIVs.

We focused on a technique called loop-mediated isothermal amplification (LAMP) [9]. This technique can be applied to the detection of RNA genomes by using reverse transcriptase. A reverse transcription LAMP (RT-LAMP) assay is usually performed within $60 \mathrm{~min}$ under isothermal conditions. The results of the RT-LAMP assay can be judged immediately with the naked eye on the basis of the turbidity or fluorescence of the reaction mixture, without the need for expensive equipment or time-consuming post-PCR processing such as gel electrophoresis $[5,14]$. The simplicity of the RT-LAMP assay should make it possible to conduct large-scale surveillance for H7N7 EIV. We have already developed the RT-LAMP assay for detection of H3N8 EIV [8]. The combination of the H3N8 RT-LAMP assay with the H7N7 RT-LAMP assay should be useful to distinguish easily between H3N8 and H7N7 EIVs. Here, we describe our development of the RT-LAMP assay for the detection of H7N7 EIV.

The H7N7 EIV strains used were A/equine/Prague/56 and A/equine/Newmarket/1/77. To determine the specificity of the RT-LAMP assay, the following common pathogens of equine respiratory disease were used: H3N8 EIV (A/equine/ Ibaraki/07, A/equine/Richmond/1/07), equine herpesvirus 1 $(89 \mathrm{c} 25 \mathrm{p})$, equine herpesvirus 2 (08c3), equine herpesvirus 4 (06c33), equine adenovirus $1(05 \mathrm{c} 3)$, equine rhinitis A virus (NM11), Getah virus (MI-110), Streptococcus equi subsp. zooepidemicus (W60), S. equi subsp. equi (CF32) and Rhodococcus equi (ATCC 33701).

From 2008 to 2011, a total of 537 nasal swabs, which were negative for EIV by the Espline test and for H7N7 
Table 1. Primers used in RT-LAMP and RT-PCR to detect H7N7 equine influenza virus

\begin{tabular}{lllll}
\hline & \multicolumn{1}{c}{ Primer } & Genome position $^{\text {a) }}$ & \multicolumn{1}{c}{ Sequence $\left(5^{\prime}-3^{\prime}\right)$} & Reference \\
\hline RT-LAMP primer & F3 & $1400-1423$ & AYTATATGAAAAGGTAAGAAGACA & This study \\
& B3 & $1647-1626$ & CAAGAAATARGAAACATGATGC & \\
& FIP (F1c-F2) & F1c: $1496-1474$ & CATGCAATCATTGTCACATTGGT- & \\
& & F2: $1434-1453$ & AATGCTGAGGAAGATGGTAA & \\
& BIP (B1c-B2) & B1c: $1542-1565$ & GAGGCAATACAAAACAGAATTCAG- & \\
& & B2: $1613-1590$ & CCAAAGTATTAYWTCTTTGTAACC & \\
& LoopF & $1473-1454$ & GRAATATTTCAAAACAGCCA & \\
& LoopB & $1570-1589$ & AYGCAGTRAAGTTGAGCAGY & \\
\hline RT-PCR primer & Forward & $160-178$ & AAAAAAACATCCCCAAGAT & 10 \\
& Reverse & $786-766$ & CTATAAAGGCCCCATTAAAAC & \\
\hline
\end{tabular}

a) Genome position according to the HA gene of A/equine/Prague/56 (GenBank accession number X62552).

EIV by RT-PCR assay, were obtained from horses with fever $\left(\geq 38.5^{\circ} \mathrm{C}\right)$. These horses were stabled in two facilities of the Japan Racing Association, namely the Miho Training Center (Ibaraki Prefecture) and the Ritto Training Center (Shiga Prefecture). The nasal samples were collected from horses by using $1.0 \times 1.5 \mathrm{~cm}$ absorbent cotton swabs and were placed in $2.5 \mathrm{~m} l$ of transport medium (PBS supplemented with $0.6 \%(\mathrm{w} / \mathrm{v})$ tryptose phosphate broth, 500 units $/ \mathrm{m} l$ penicillin, $500 \mu \mathrm{g} / \mathrm{m} l$ streptomycin and $1.25 \mu \mathrm{g} / \mathrm{m} l$ amphotericin B). In the Espline test, $200 \mu l$ of nasal swabs was used to detect EIV, and the procedure was conducted as previously described [16].

Viral nucleic acids were extracted from $100 \mu l$ of nasal swabs, allantoic fluids or culture supernatants with a nucleic acid isolation kit (MagNA Pure LC Total Nucleic Acid Isolation Kit, Roche Diagnostics GmbH, Mannheim, Germany), and bacterial DNA samples were extracted from culture of these strains with a nucleic acid purification kit (InstaGene Matrix, Bio-Rad Laboratories, Hercules, CA, U.S.A.).

The RT-PCR assay was performed with a primer set specific for detection of the hemagglutinin (HA) gene of H7N7 EIV (Table 1) [10] using an RT-PCR kit (Qiagen OneStep RT-PCR Kit, Qiagen GmbH, Hilden, Germany). The RTPCR conditions were as follows: reverse transcription at $50^{\circ} \mathrm{C}$ for $30 \mathrm{~min}$ and then at $95^{\circ} \mathrm{C}$ for $15 \mathrm{~min} ; 40$ cycles of denaturation at $94^{\circ} \mathrm{C}$ for $1 \mathrm{~min}$, annealing at $52^{\circ} \mathrm{C}$ for $1 \mathrm{~min}$ and extension at $72^{\circ} \mathrm{C}$ for $1 \mathrm{~min}$; and then a final extension at $72^{\circ} \mathrm{C}$ for $10 \mathrm{~min}$. The RT-PCR products were kept at $4^{\circ} \mathrm{C}$ until the samples had been analyzed by using $1.2 \%$ agarose gel electrophoresis (FlashGel System for DNA, Lonza Rockland, Inc., Rockland, ME, U.S.A.).

The RT-LAMP primer set for the HA gene of H7N7 EIV was designed by using the PrimerExplorer V4 software (Fujitsu Limited, Tokyo, Japan). The sequences and locations of the primers used for the RT-LAMP assay are shown in Table 1. The reaction mixture was prepared by using an RNA amplification kit (Loopamp, Eiken Chemical Co., Ltd., Tokyo, Japan), as described previously [7, 8]. The RT-LAMP assay was performed at $60^{\circ} \mathrm{C}$ for $60 \mathrm{~min}$, and then the mixture was heated at $80^{\circ} \mathrm{C}$ for $5 \mathrm{~min}$ to inactivate the enzyme reaction. The RT-LAMP products were detected by monitoring the turbidity using a real-time turbidimeter (Loopamp LA-320C,
Eiken Chemical Co., Ltd.). A turbidity of $\geq 0.1$ was considered positive in the RT-LAMP assay. When the results of the RT-LAMP reactions were judged visually, calcein (Loopamp Fluorescent Detection Reagent, Eiken Chemical Co., Ltd.) was added to the reaction mixture before the reaction. The mixture turns green in the presence of calcein when the RT-LAMP reaction is positive, whereas the mixture remains orange when the result is negative. One Nde I restriction site is present in the sequence amplified by the RT-LAMP assay. To confirm the specificity of the RT-LAMP reaction, the products were digested by a restriction enzyme, Nde I (Takara Bio Inc., Shiga, Japan), and the resultant products of the expected length were observed by gel electrophoresis (data not shown).

Using serial decimal dilutions of A/equine/Prague/56, a representative strain of H7N7 EIV $\left(10^{8.0} 50 \%\right.$ egg infectious dose $/ 200 \mu l$ ), the detection limit of the RT-LAMP assay was compared with that of the Espline test and the RT-PCR assay (Fig. 1). The detection limit of the RT-LAMP assay was a virus dilution of $10^{-4}$, which was 10 times more sensitive than that of the Espline test and the same as that of the RTPCR assay. There was no difference in the sensitivity of the RT-LAMP assay when monitoring was performed with the turbidimeter or by visual observation. To evaluate the specificity of the RT-LAMP assay, it was performed on another H7N7 EIV and on several other viral and bacterial pathogens of horses. The RT-LAMP assay also amplified the RNAs of H7N7 EIV (A/equine/Newmarket/1/77). However, no nucleic acids of the other viruses and bacteria examined were amplified (data not shown). Nasal swabs $(n=537)$ were tested for the presence of H7N7 EIV by using the RT-LAMP assay, and all nasal swabs were negative for H7N7 EIV. These results indicated that the RT-LAMP assay is highly specific for H7N7 EIV.

An RT-LAMP reaction can be performed at a constant temperature and within $1 \mathrm{hr}$. The results of the RT-LAMP assay can be judged by visual observation with the naked eye immediately after the reaction. Because it provides high sensitivity and ease of manipulation without the need for a thermal cycler or gel electrophoresis, the RT-LAMP assay is suitable for large-scale surveillance for H7N7 EIV. In addition, the combination of the H7N7 RT-LAMP assay with the 


\section{A. RT-LAMP}
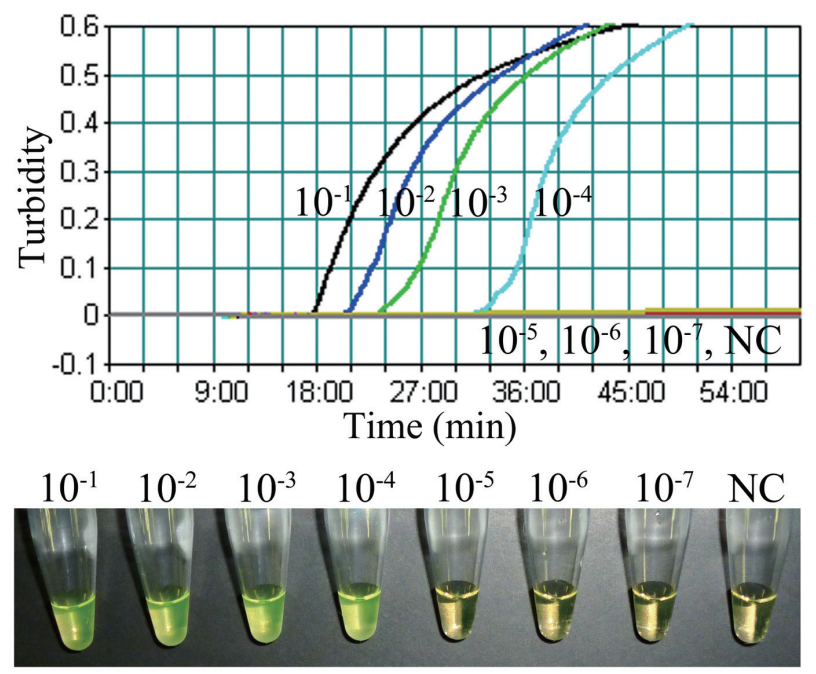

\section{B. Espline}

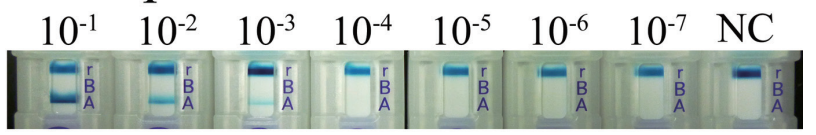

\section{RT-PCR}

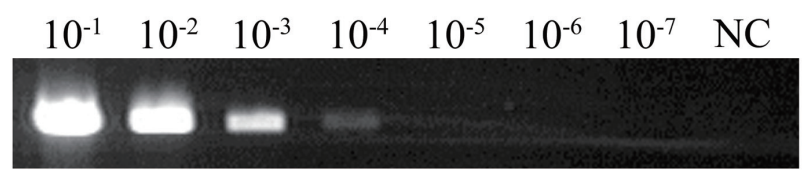

Fig. 1. Detection limits of the RT-LAMP assay, the Espline test and the RT-PCR assay for equine influenza virus of the H7N7 subtype (A/equine/Prague/56, $10^{8.0}$ egg infectious dose ${ }_{50} / 200 \mu l$ ). (A) Sensitivity of the RT-LAMP assay monitored by real-time measurement of turbidity (upper panel) and by visual observation (lower panel). (B) Sensitivity of the Espline test. (C) Sensitivity of the RT-PCR assay. The RT-LAMP assay, the Espline test and the RT-PCR assay were performed with serial 10 -fold dilutions of A/equine/Prague/56 ( $10^{-1}$ to $10^{-7}$ virus dilutions). $\mathrm{NC}=$ negative control.

H3N8 RT-LAMP assay is useful for discriminating between H3N8 and H7N7 EIVs in clinical laboratories.

ACKNOWLEDGMENTS. A/equine/Prague/56 was obtained from the Faculty of Agriculture, University of Tokyo, Tokyo, Japan. A/equine/Newmarket/1/77 was obtained from the National Institute of Infectious Diseases, Tokyo, Japan. A/equine/Richmond/1/07 was obtained from the Animal Health Trust, Newmarket, Suffolk, UK. The authors are grateful to Ms. Kaoru Makabe, Ms. Kazue Arakawa, Mr. Akira Kokubun, Ms. Akiko Suganuma and Ms. Fumie Watanabe for their invaluable technical assistance.

\section{REFERENCES}

1. Chambers, T. M., Shortridge, K. F., Li, P. H., Powell, D. G. and
Watkins, K. L. 1994. Rapid diagnosis of equine influenza by the Directigen FLU-A enzyme immunoassay. Vet. Rec. 135: 275279. [Medline] [CrossRef]

2. Lu, Z., Chambers, T. M., Boliar, S., Branscum, A. J., Sturgill, T. L., Timoney, P. J., Reedy, S. E., Tudor, L. R., Dubovi, E. J., Vickers, M. L., Sells, S. and Balasuriya, U. B. 2009. Development and evaluation of one-step TaqMan real-time reverse transcriptionPCR assays targeting nucleoprotein, matrix, and hemagglutinin genes of equine influenza virus. J. Clin. Microbiol. 47: 39073913. [Medline] [CrossRef]

3. Madic, J., Martinovic, S., Naglic, T., Hajsig, D. and Cvetnic, S. 1996. Serological evidence for the presence of A/equine-1 influenza virus in unvaccinated horses in Croatia. Vet. Rec. 138: 68. [Medline] [CrossRef]

4. McCabe, V. J., Sindle, T. and Daly, J. M. 2006. Evaluation of the Binax NOW Flu A test kit for the rapid detection of equine influenza virus. Vet. Rec. 158: 164-165. [Medline] [CrossRef]

5. Mori, Y., Nagamine, K., Tomita, N. and Notomi, T. 2001. Detection of loop-mediated isothermal amplification reaction by turbidity derived from magnesium pyrophosphate formation. Biochem. Biophys. Res. Commun. 289: 150-154. [Medline] [CrossRef]

6. Morley, P. S., Bogdan, J. R., Townsend, H. G. and Haines, D. M. 1995. Evaluation of Directigen Flu A assay for detection of influenza antigen in nasal secretions of horses. Equine Vet. J. 27: 131-134. [Medline] [CrossRef]

7. Nemoto, M., Imagawa, H., Tsujimura, K., Yamanaka, T., Kondo, T. and Matsumura, T. 2010. Detection of equine rotavirus by reverse transcription loop-mediated isothermal amplification (RTLAMP). J. Vet. Med. Sci. 72: 823-826. [Medline] [CrossRef]

8. Nemoto, M., Yamanaka, T., Bannai, H., Tsujimura, K., Kondo, T. and Matsumura, T. 2011. Development and evaluation of a reverse transcription loop-mediated isothermal amplification assay for H3N8 equine influenza virus. J. Virol. Methods 178: 239-242. [Medline] [CrossRef]

9. Notomi, T., Okayama, H., Masubuchi, H., Yonekawa, T., Watanabe, K., Amino, N. and Hase, T. 2000. Loop-mediated isothermal amplification of DNA. Nucleic Acids Res. 28: E63. [Medline] [CrossRef]

10. Oxburgh, L. and Hagstrom, A. 1999. A PCR based method for the identification of equine influenza virus from clinical samples. Vet. Microbiol. 67: 161-174. [Medline] [CrossRef]

11. Paillot, R., Hannant, D., Kydd, J. H. and Daly, J. M. 2006. Vaccination against equine influenza: quid novi? Vaccine 24: 40474061. [Medline] [CrossRef]

12. Quinlivan, M., Cullinane, A., Nelly, M., Van Maanen, K., Heldens, J. and Arkins, S. 2004. Comparison of sensitivities of virus isolation, antigen detection, and nucleic acid amplification for detection of equine influenza virus. J. Clin. Microbiol. 42: 759-763. [Medline] [CrossRef]

13. Quinlivan, M., Dempsey, E., Ryan, F., Arkins, S. and Cullinane, A. 2005. Real-time reverse transcription PCR for detection and quantitative analysis of equine influenza virus. J. Clin. Microbiol. 43: 5055-5057. [Medline] [CrossRef]

14. Tomita, N., Mori, Y., Kanda, H. and Notomi, T. 2008. Loopmediated isothermal amplification (LAMP) of gene sequences and simple visual detection of products. Nat. Protoc. 3: 877-882. [Medline] [CrossRef]

15. van Maanen, C. and Cullinane, A. 2002. Equine influenza virus infections: an update. Vet. Q. 24: 79-94. [Medline] [CrossRef]

16. Yamanaka, T., Tsujimura, K., Kondo, T. and Matsumura, T. 2008. Evaluation of antigen detection kits for diagnosis of equine influenza. J. Vet. Med. Sci. 70: 189-192. [Medline] [CrossRef] 